\title{
LONG-TERM EFFECTS OF BURN SEASON AND FREQUENCY ON PONDEROSA PINE FOREST FUELS AND SEEDLINGS
}

\author{
Douglas J. Westlind* and Becky K. Kerns \\ USDA Forest Service, Pacific Northwest Research Station, Forestry Sciences Laboratory, \\ 3200 SW Jefferson Way, Corvallis, Oregon 97331, USA \\ *Corresponding author: Tel.: +1-541-750-7376; e-mail: dwestlind@fs.fed.us
}

\begin{abstract}
Prescribed fire is widely applied in western US forests to limit future fire severity by reducing tree density, fuels, and excessive seedlings. Repeated prescribed burning attempts to simulate historical fire regimes in frequent-fire forests, yet there is limited long-term information regarding optimal burn season and frequency. In addition, burns are operationally feasible only in the spring and late fall, largely outside the historical wildfire season. This study quantifies the effect of seasonal reburns on woody surface fuels, forest floor fuels, and understory tree regeneration abundance in six previously thinned ponderosa pine (Pinus ponderosa Lawson \& C.
\end{abstract} Lawson) stands in the southern Blue Mountain Ecoregion of Oregon, USA. Each stand consisted of an unburned control, and four season by reburn treatments: spring $5 \mathrm{yr}$, spring $15 \mathrm{yr}$, fall $5 \mathrm{yr}$, and fall $15 \mathrm{yr}$. We evaluated season and frequency of reburn for woody surface fuel (1 $\mathrm{hr}$ to $1000 \mathrm{hr}$ ), forest floor fuel (litter and duff, undifferentiated), and understory conifer seedling density (regeneration). Burning was initiated in the fall of 1997 and spring of 1998; we present results in this pa-

\section{RESUMEN}

Las quemas prescritas se aplican de manera amplia en los bosques del oeste de los EEUU, para limitar la severidad de fuegos futuros ya que reduce la densidad de árboles, el combustible y la cantidad excesiva de renovales. Las quemas repetidas intentan simular el régimen de fuegos históricos en bosques con fuegos frecuentes, aunque la información a largo plazo respecto a la frecuencia y la estación óptima para quemar es escasa. Además, las quemas son operacionalmente factibles sólo en la primavera y en el otoño tardío, bastante por fuera de la estación histórica de incendios naturales. Este estudio cuantifica el efecto de las quemas repetidas estacionalmente en combustibles leñosos superficiales, en combustibles sobre el suelo forestal y en la abundancia de la regeneración de árboles en el estrato inferior del bosque en seis rodales de pino ponderosa (Pinus ponderosa Lawson \& C. Lawson), previamente raleados en la eco-región de las Montañas Azules de Oregon, EEUU. Cada uno de los rodales consistió en: un control sin quemar, y los otros cuatro tratamientos con quemas repetidas: en primavera cada 5 años, en primavera cada 15 años, en otoño cada 5 años y en otoño cada 15 años. Nosotros evaluamos la estación y la frecuencia para los combustibles leñosos superficiales ( $1 \mathrm{~h}$ a $1000 \mathrm{~h}$ ), combustibles sobre el suelo del bosque (hojarasca y materia orgánica descompuesta, indiferenciada), y densidad de renovales de coníferas en el estrato inferior del bosque (regeneración). Las quemas fueron iniciadas en el otoño de 1997 y en la primavera de 1998; noso- 
per through 2014 for fuel, and 2015 for seedlings. All reburn treatments reduced the forest floor depth compared to those areas not burned (controls). Fall burning, regardless of frequency, generated $1000 \mathrm{hr}$ fuel primarily from overstory mortality resulting from the initial entry burns and subsequent snag and branch fall. But, for the other woody fuel types, reburning had minimal impact, regardless of season or frequency. All reburn treatments reduced regeneration survival, but $5 \mathrm{yr}$ fall reburning was most effective in reducing excessive conifer seedlings. Repeated spring or fall reburns following thinning will reduce forest floor depth but, to achieve low woody fuel loads and control excessive conifer regeneration, it may be necessary to conduct reburns using different timing, such as during drier periods when wildfire ignitions by lightning occurred historically. tros presentamos en este trabajo los resultados para combustibles durante el año 2014 y para renovales durante el año 2015. Todos los tratamientos de quemas repetidas redujeron la profundidad del suelo forestal comparado con aquellas áreas que no fueron quemadas (controles). Las quemas de otoño, sin tener en cuenta la frecuencia, generaron combustibles de $1000 \mathrm{~h}$ principalmente como resultado de la mortalidad inicial por fuego del dosel superior y la subsecuente caída de troncos y ramas. Pero para los otros tipos de combustible leñoso, las quemas repetidas tuvieron un impacto mínimo, cualquiera fuese la estación o la frecuencia. Todos los tratamientos de quemas repetidas redujeron la supervivencia de la regeneración, pero el tratamiento de quemas en otoño cada 5 años fue el más efectivo en reducir el exceso de plantines de coníferas. Las quemas repetidas en primavera u otoño seguidas de raleos reducirán la profundidad del suelo forestal, pero para lograr cargas bajas de combustible leñoso y controlar la excesiva cantidad de regeneración de coníferas, puede ser necesario conducir las quemas repetidas utilizando diferentes momentos, como durante períodos más secos cuando la ignición de fuegos naturales por rayos han ocurrido históricamente.

Keywords: Blue Mountain Ecoregion, fire regimes, fuel reduction, re-entry burning

Citation: Westlind, D.J., and B.K. Kerns. 2017. Long-term effects of burn season and frequency on ponderosa pine forest fuels and seedlings. Fire Ecology 13(3): 42-61. doi: 10.4996/ fireecology. 130304261

\section{INTRODUCTION}

Prescribed fire is a widely applied tool for lowering future wildfire severity in western US ponderosa pine (Pinus ponderosa Lawson \& C. Lawson) forests by reducing tree density, fuels, and excessive conifer seedlings (Agee and Lolley 2006, Schwilk et al. 2009, Stephens et al. 2009). Ponderosa pine forests are widely distributed in North America (Mirov 1967), occurring primarily in low to mid elevations that historically developed in conjunction with frequent low and mixed severity wildfires (Pyne 1982, Hessburg and Agee 2003). European settlement and related land management practices such as fire suppression and overgrazing interrupted the historical fire regime, advancing secondary succession and the creation of denser stands, accumulation of woody and forest floor fuel, and greater fuel connectivity, increasing the potential for high-severity stand-replacing wildfire (Mutch et al. 1993; Covington and Moore 1994; Agee 1996a, b; Belsky and Blumenthal 1997; Kolb et al. 1998; Hessburg et al. 1999; Hessburg et al. 2000; Hessburg et al. 2005; Marlon et al. 
2012). Anthropogenic climate change is further contributing to increased forest disturbance occurrence (Westerling et al. 2006, Littell et al. 2009, Dennison et al. 2014), primarily due to fuel aridity (Peterson and Marcinkowski 2014, Abatzoglou and Williams 2016). In addition to greater risk of high-severity fire, dense stand conditions and water deficits increase forest susceptibility to disease and insect attack (Castello et al. 1995, Covington et al. 1997, Fettig et al. 2007).

While thinning and prescribed fire are widely used and examined either alone or in combination, studies in the western US that examine more than a single season, burn entry, or long-term results are rare. Thus, optimal regimes necessary to reach and maintain desired low fuel loads and limit conifer regeneration are not well documented. Limited information about treatment longevity in ponderosa pine forests suggests that fuels can accumulate to near pre-treatment levels within a few years (Keifer et al. 2006, Chiono et al. 2012), and treatments can promote abundant conifer regeneration and survival (Bonnet et al. 2005, Zald et al. 2008). Thus periodic reburning through prescribed fire or managed wildfire is necessary to retain resilient conditions in which wildfire can occur without severely damaging consequences (Agee 1996a, McCandliss 2002, Reinhardt et al. 2008, Stephens et al. 2012, Vaillant et al. 2015).

Selection of reburn frequency is typically guided by local and regional historical fire return interval information. The overall impact on fuel loads of varying fire return frequency is not well documented. More frequent burning is often assumed to reduce fuel loads more effectively; however, longer fire return intervals allow more fuel buildup (Keifer et al. 2006, Chiono et al. 2012, Vaillant et al. 2015), likely resulting in greater consumption when burned. Mean fire return intervals (MFRI) for ponderosa pine forests in the western US vary from $3 \mathrm{yr}$ to $43 \mathrm{yr}$, depending on climate, vegetation type, and topographic and geologic features that either restrict or facilitate fire spread (Stephens and Moghaddas 2005). In Oregon and Washington, MFRIs for ponderosa pine forests range from $3 \mathrm{yr}$ to $36 \mathrm{yr}$ (Soeriaatmadja 1966, Bork 1984, Heyerdahl et al. 2001, Heyerdahl et al. 2008, Johnston 2016).

Prescribed burning is largely restricted to two seasonal opportunities when weather and moisture conditions exist to maintain control and personnel are available to conduct the burns: the spring following snow melt as fine fuel begins to dry, but before extensive annual vegetative growth, and late fall as temperatures decrease and humidity rises. However, in the US Intermountain West, the majority of lightning-caused wildfire ignitions occur in July and August in conjunction with the hottest and driest time of year (Westerling et al. 2003, Short 2015). In general, fall burns are of higher severity (Ryan and Reinhardt 1988, Thies et al. 2005, Fettig et al. 2010) due to lower moisture in large fuels (Estes et al. 2012), and consume more of the larger woody fuels (Fettig et al. 2010) as well as forest floor fuel (Perrakis and Agee 2006, Progar et al. 2017). Yet late spring burns can more effectively reduce forest floor fuel than fall burns, demonstrating that fuels are not always drier and more extensively consumed in the fall as compared to the spring (Kauffman and Martin 1989). But these results are from initial entry burns following long periods of fire absence, and may not be true of reburning.

We are aware of no long-term studies in the western US in the published literature that have measured fuel in relation to different seasonal burn frequencies. The objectives of this study are twofold: 1) compare the effect of reburn season (spring, fall) and frequency (5 yr and $15 \mathrm{yr}$ ) on fuel in the ponderosa pine forests of the southern Blue Mountain Ecoregion of Oregon, and 2) describe the fuel dynamics of $5 \mathrm{yr}$ seasonal reburning in these same forests. The fuel measured for both objectives includes dead and downed woody surface fuel, forest floor depth, change in fuel load (con- 
sumption), and conifer regeneration. Our prescribed fire treatments were selected based on traditional seasonal burn windows available to managers, on what was known about fire return intervals at the time the study was initiated in 1997, and on the management goal of reducing woody surface fuel, limiting establishment of seedlings and saplings, and reducing potential fire severity. Early work in the region reported MFRIs ranging from $4 \mathrm{yr}$ to 11 yr (Bork 1984), 3 yr to 36 yr (Soeriaatmadja 1966), and 15 yr (Agee 1996b). We hypothesized that fuel loads would be reduced and conifer regeneration controlled more by fall than spring reburns, and reduced more by reburning at $5 \mathrm{yr}$ than $15 \mathrm{yr}$ frequencies.

\section{METHODS}

\section{Study Sites}

We established this study in 1997 in six stands of multi-aged ponderosa pine with scattered mountain mahogany (Cercocarpus ledifolius Nutt.) and western juniper (Juniperus occidentalis Hook.) in the southern Blue Mountain Ecoregion of central eastern Oregon (Emigrant Creek Ranger District, Malheur National Forest). Four stands are in the eastern part of the district (Driveway Springs) and two are in the western portion (Trout Creek and Kidd Flat). The ponderosa pine range in age from $100 \mathrm{yr}$ to $120 \mathrm{yr}$ with scattered individuals up to $250 \mathrm{yr}$. It appeared that the stands had not experienced wildfire for a long period as there was no recorded documentation or field observation of recent fire, but fire scars were evident on older trees. All of the stands had a history of selective harvest beginning in the 1920s. Stands ranged in area from 19.8 ha to 55.7 ha and were thinned from below in 1994 or 1995 to tree densities of from 181 trees $\mathrm{ha}^{-1}$ to 252 trees $\mathrm{ha}^{-1}$, with mean dbh ranging from $25.5 \mathrm{~cm}$ to $31.8 \mathrm{~cm}$. Initial prescribed burns were completed in fall 1997 and spring 1998 for the purpose of fuel reduction, to stimulate understory vegetation growth, and to reduce stocking of small-diameter trees. Elevations ranged from $1570 \mathrm{~m}$ to $1740 \mathrm{~m}$ and climates were typical of the southern Blue Mountain Ecoregion, characterized by cold winters and hot dry summers. Water year (October to September) average annual precipitation (1981 to 2014) was $46 \mathrm{~cm}$, with most precipitation in the form of snow between October and April (USDA NRCS 2012). Surface fuel consisted of a combination of logging slash, dry grasses, pine needles, and naturally accumulated woody debris. Further details about the initial 1997 and 1998 burns, tree mortality, and stand structure can be found in Thies et al. (2005), understory vegetation in Kerns et al. (2006) and Kerns et al. (2011), soils in Hatten et al. (2008), and fuel four years following the initial burns in Kerns et al. (2011).

\section{Experimental Design}

In 1997, we divided each previously thinned stand into three season-of-burn treatment units along boundaries coinciding with topographic features or roads to allow for ease in control of the prescribed burns. Treatment units ranged in size from 2.6 ha to 18.4 ha. We randomly assigned a burn treatment of fall, spring, or control (no burn) to each experimental unit in each stand. Initial burns were conducted in October 1997 and June 1998. In 2002, five years after the initial fall burns, the fall and spring treatment units were split and randomly assigned a $5 \mathrm{yr}$ or $15 \mathrm{yr}$ repeat burn (hereafter referred to as reburn) frequency treatment. The first and second reburns for the $5 \mathrm{yr}$ frequency units were conducted in October 2002 and 2007, and June 2003 and 2008, for fall and spring, respectively. Reburns one and two for the $5 \mathrm{yr}$ frequency were conducted in October 2002 and 2007, and June 2003 and 2008, for fall and spring, respectively. Reburn three of the $5 \mathrm{yr}$ frequency and reburn one of the $15 \mathrm{yr}$ frequency were applied to two stands in October 2012 and May 2013, but a limited burn window in the fall of 2012 prevented 
burning in four stands until October 2013 and May 2014 (a one-year delay). Information regarding burn type, individual burn dates, weather conditions, and flame lengths are provided in Table 1.

\section{Field Measurements}

After the initial burns, we systematically established six 0.20 ha circular sampling plots along transects within each burn season treatment unit to evaluate post-fire tree growth, mortality, disease, and vegetation response (Thies et al. 2005, Kerns et al. 2006). Following the split to study reburn frequency the controls contained six plots and the reburn units each had three. This was expanded to seven plots per unit by adding one to the controls and four to each reburn treatment. These new plots were established $50 \mathrm{~m}$ minimum at a random azimuth from the existing plots to prevent overlap and double sampling. Two $20.1 \mathrm{~m}$ long fuel inventory transects were established at each plot center: one on a randomly chosen azimuth and another 180 degrees opposite. This resulted in 14 fuel transects within each of the season by frequency treatment units at each of the six stands.

We inventoried woody surface fuels along each transect using the planar intercept method outlined in Brown (1974) prior to reburning for all treatments and again following the fires in the burned treatments. The $1 \mathrm{hr}$ fuels $(0 \mathrm{~cm}$ to $0.64 \mathrm{~cm})$ and $10 \mathrm{hr}$ fuels $(0.64 \mathrm{~cm}$ to 2.54 $\mathrm{cm})$ were tallied for the first $1.2 \mathrm{~m}$, while 100 hr fuels $(2.54 \mathrm{~cm}$ to $7.62 \mathrm{~cm})$ and $1000 \mathrm{hr}$ fuels $(>7.62 \mathrm{~cm})$ were tallied over the entire 20.1 $\mathrm{m}$ length. In addition, we recorded species, diameter, and condition (sound or decayed) for $1000 \mathrm{hr}$ fuels. We measured the forest floor (O horizon) depth at $6 \mathrm{~m}$ and $12 \mathrm{~m}$ along each transect. Litter and duff were not differentiated due to site aridity limiting duff development and layer mixing from multiple disturbances (i.e., mechanical ground-based thinning, multiple burns, and cattle grazing with

Table 1. Treatment, year, ignition date, weather conditions, and flame lengths for prescribed burns from 1997 through 2014 for the season and frequency of burn study in the Blue Mountain Ecoregion, Oregon, USA.

\begin{tabular}{|c|c|c|c|c|c|c|}
\hline Treatment & Year & Ignition date & $\begin{array}{l}\text { Temperature } \\
\text { range }\left({ }^{\circ} \mathrm{C}\right)\end{array}$ & $\begin{array}{c}\text { Relative } \\
\text { humidity (\%) }\end{array}$ & $\begin{array}{c}\text { Wind speed } \\
\left(\mathrm{km} \mathrm{hr}^{-1}\right)\end{array}$ & $\begin{array}{c}\text { Flame length } \\
(\mathrm{m})\end{array}$ \\
\hline Initial fall burn & 1997 & $30 \mathrm{Sep}, 16$ Oct & 13.9 to 20.6 & 24 to 40 & 0.0 to 8.0 & 0.0 to 1.5 \\
\hline Initial spring burn & 1998 & 17 Jun & 15.5 to 21.7 & 12 to 44 & 3.2 to 8.0 & 0.6 to 1.5 \\
\hline Fall reburn 1 & 2002 & 8,9 Oct & 10.5 to 18.3 & 17 to 44 & 0.0 to 11.3 & 0.3 to 0.9 \\
\hline Spring reburn 1 & 2003 & 22 May & 21.1 to 23.3 & 30 to 32 & 0.0 to 9.7 & 0.3 to 0.6 \\
\hline Fall reburn 2 & 2007 & 13,15 Oct & 10.0 to 16.1 & 32 to 54 & 0.0 to 3.2 & 0.0 to 0.9 \\
\hline Spring reburn 2 & 2008 & 19 May, 14 Jun & 23.9 to 30.0 & 19 to 30 & 0.0 to 8.0 & 0.3 to 1.2 \\
\hline $\begin{array}{l}\text { Fall reburn } 3^{\mathrm{a}}(5 \mathrm{yr}) \\
\text { Fall reburn } 1^{\mathrm{a}}(15 \mathrm{yr})\end{array}$ & 2012 & 18 Oct & 16.1 to 16.7 & 22 to 25 & 1.6 to 6.4 & 0.2 to 0.6 \\
\hline $\begin{array}{l}\text { Spring reburn } 3^{\mathrm{a}}(5 \mathrm{yr}) \\
\text { Spring reburn } 1^{\mathrm{a}}(15 \mathrm{yr})\end{array}$ & 2013 & 3, 7 May & 15.6 to 25.6 & 21 to 33 & 0.0 to 8.0 & 0.2 to 0.6 \\
\hline $\begin{array}{l}\text { Fall reburn } 3^{\mathrm{b}}(5 \mathrm{yr}) \\
\text { Fall reburn } 1^{\mathrm{b}}(15 \mathrm{yr})\end{array}$ & 2013 & 22,24 Oct & 15.0 to 18.9 & 26 to 41 & 0.0 to 4.8 & 0.2 to 0.6 \\
\hline $\begin{array}{l}\text { Spring reburn } 3^{\mathrm{b}}(5 \mathrm{yr}) \\
\text { Spring reburn } 1^{\mathrm{b}}(15 \mathrm{yr})\end{array}$ & 2014 & 14 May & 19.4 to 22.2 & 19 to 24 & 1.6 to 8.0 & 0.3 to 0.9 \\
\hline
\end{tabular}


no post-burn rest period). We tallied understory conifer regeneration by species in two classes based on seedling height: $\leq 0.4 \mathrm{~m}$, and $>0.4$ $\mathrm{m}$ to $1.37 \mathrm{~m}$, hereafter referred to as short and tall seedlings, respectively. This was done one full growing season after each reburn in 2004, 2009 , and 2015, within a nested 0.03 ha circular subplot, at five of the six stands. The schedule for fuel transect and seedling data collection is presented in Table 2 .

\section{Data Analysis}

We determined mass of the smaller size fuel classes ( $1 \mathrm{hr}$ to $100 \mathrm{hr}$ ) using the nonslash average square diameter, specific gravity, non-horizontal particle angles, and formulas from Brown (1974). For calculation of 1000 $\mathrm{hr}$ fuel mass, we used specific gravities of 0.40 for ponderosa pine (Brown 1974), 0.54 for juniper (Miles and Smith 2009), and 0.81 for mountain mahogany (Chojnacky 1984). We corrected the specific gravities for decayed ponderosa pine and juniper using a 0.75 multiplier (Brown 1974); no decayed mountain mahogany was encountered. We averaged tran- sect data means for each surface fuel size class, forest floor depth, and density of conifer seedling class in treatment experimental units for analysis. We lumped and analyzed all species of conifer seedlings as a single group as ponderosa pine was the primary component ( $>95 \%)$, although western juniper occurred occasionally, with Douglas-fir (Pseudotsuga menziesii [Mirb.] Franco), and grand fir (Abies grandis [Doug.] Lindl) occurring very rarely. We estimated the consumption of dead and downed woody debris and forest floor fuel as the change in fuel load by subtracting the postburn from the pre-burn values for analysis. Due to the short time lag between measurements combined with any interim fuel recruitment, our estimates for fuel consumption can be negative.

We compared burn parameter means for air temperature, relative humidity, wind speed, and flame length, between fall and spring burns through $t$-tests using the Satterthwaite correction (Welch's $t$-test) for unequal variance using the TTEST procedure in SAS 9.4 (SAS 2014).

Table 2. Field data collection by year, treatment, and type, for the season and frequency of burn study in the Blue Mountain Ecoregion, Oregon, USA. F = downed, dead woody fuel and forest floor fuel depth (litter and duff), $\mathrm{S}=$ seedling.

\begin{tabular}{ccccccc}
\hline & \multicolumn{5}{c}{ Treatment } & \\
\cline { 2 - 5 } Year & Control & Fall 5 yr & Fall 15 yr & Spring 5 yr & Spring 15 yr & Type \\
\hline 2002 & F & F & F & F & F & Pre fire \\
\hline 2003 & F & F & & F & & Post fire \\
\hline 2004 & S & S & & S & & Post fire \\
\hline 2007 & F & F & & F & & Pre fire \\
\hline 2008 & F & F & & F & & Post fire \\
\hline 2009 & S & S & & S & & Post fire \\
\hline 2012 & F & F & F & F & F & Pre fire \\
\hline $2013^{\mathrm{a}}$ & F & F & F & F & F & Post fire \\
\hline $2014^{\mathrm{b}}$ & F & F & F & F & F & Post fire \\
\hline 2015 & S & S & S & S & S & Post fire \\
\hline${ }^{\mathrm{a} T w o ~ s t a n d s ~}$ & & & & & \\
${ }^{\mathrm{b}}$ Four stands & & & & &
\end{tabular}




\section{Objective 1-Comparison of $5 \mathrm{yr}$ and $15 \mathrm{yr}$ Seasonal Reburning}

To assess fuel load differences of seasonal reburning at $5 \mathrm{yr}$ and $15 \mathrm{yr}$ frequencies, we analyzed the 2014 fuel and the 2015 seedling data (for all treatments) as a randomized block incomplete split-plot, with season of reburn (fall, spring, and control) as the whole plot, and frequency of burn ( $5 \mathrm{yr}$ and $15 \mathrm{yr}$ ) as the split-plot. Controls are incomplete split-plots as they have no frequency, thus we defined treatment as the combination of season and frequency of burn resulting in five treatments: control, fall $5 \mathrm{yr}$, spring $5 \mathrm{yr}$, fall $15 \mathrm{yr}$, and spring $15 \mathrm{yr}$. We modeled treatment as a fixed effect and stand as a random effect. We assessed these simple effect (treatment) differences through paired contrasts (Aastveit et al. 2009). Since consumption data does not exist for the control plots, we analyzed the 2014 consumption data as a randomized block complete split-plot design with season of burn (fall and spring) as the whole plot, and frequency of burn (5 yr and $15 \mathrm{yr}$ ) as the split-plot. We modeled season and frequency of reburn as fixed effects and stand as a random effect.

\section{Objective 2-Five Year Seasonal Reburn Dynamics}

To evaluate changes in fuel loads over time following reburning at $5 \mathrm{yr}$ frequencies, we analyzed the fuel data (control and $5 \mathrm{yr}$ frequency treatments only) as a randomized complete block, repeated measures design, with season of reburn (fall, spring, and control) as the whole plot, and year (2003, 2008, 2014) repeated. Season and year were treated as fixed effects, stand as a random effect. The 5 yr frequency consumption data were similarly analyzed except controls were not included.

All statistical analyses for objectives 1 and 2 were completed using the mixed procedure for linear mixed models in SAS 9.4 (SAS 2014). Assumptions of normality and equal variance of the residuals were checked during analysis through the use of quantile-quantile and residual versus predicted plots, respectively. For the repeated measures analysis, we fit statistical models using compound symmetry, heterogonous compound symmetry, unstructured, spatial power, Toeplitz, and autoregressive covariance structures (Littell et al. 2006.) We chose spatial power and unstructured as our final covariance structures for the fuels progression and consumption analyses, respectively, based on a combination of the suitability to our data and the lowest Akaike Information Criterion (AIC) score (Akaike 1981). We used a natural log transformation for the seedling regeneration data and reported back-transformed means and 95\% confidence limits; no other transformations of the data were necessary. We were willing to accept the possibility of type I error in a large field experiment such as this, so for the incomplete split-plot analyses, we chose to not correct for multiple comparisons. For all other analyses, we used Fischer's least significant differences (LSD) for our comparisons rather than a family correction method. We considered effects significant based upon $\alpha=0.05$, and marginally significant when $\alpha>0.05$ to $\alpha \leq 0.10$.

\section{RESULTS}

Air temperature was different during the spring and fall burns $\left(t_{6.4}=3.84, P=0.008\right)$, with the mean spring temperatures estimated to be $6.22^{\circ} \mathrm{C}$ higher $\left(95 \% \mathrm{CI} ; 3.32^{\circ} \mathrm{C}\right.$ to $10.12^{\circ} \mathrm{C}$ ) than fall temperatures. There were no differences between spring and fall burns for mean relative humidity, wind speed, or flame length, all $P \geq 0.134$.

\section{Objective 1-Comparison of $5 \mathrm{yr}$ and $15 \mathrm{yr}$ Seasonal Reburning}

In 2014, there were no treatment differences for $1 \mathrm{hr}$ woody fuel (for all comparisons $P \geq$ 0.19; Figure 1A), but there was $1.19 \mathrm{Mg} \mathrm{ha}^{-1}$ 


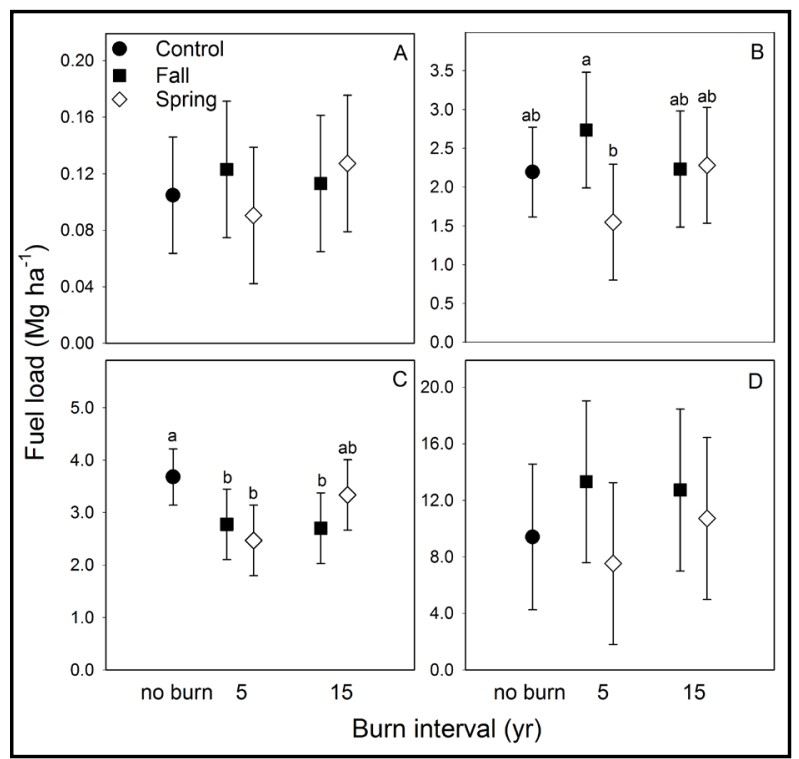

Figure 1. Woody surface fuel $\left(\mathrm{Mg} \mathrm{ha}^{-1}\right)$ of (A) 1 hr, (B) $10 \mathrm{hr}$, (C) $100 \mathrm{hr}$, and (D) $1000 \mathrm{hr}$ lag-time, in 2014 following spring and fall reburns at $5 \mathrm{yr}$ (three reburns) and $15 \mathrm{yr}$ (one reburn) frequencies in the Blue Mountain Ecoregion, Oregon, USA. Bars represent $95 \%$ confidence limits. Within fuel type, when differences exist, treatments not sharing the same letter are different at $\alpha=0.05$.

more $10 \mathrm{hr}$ fuel in the fall $5 \mathrm{yr}$ treatment (Figure 1B) than the spring $5 \mathrm{yr}$ treatment $\left(t_{23.2}=\right.$ $2.29, P=0.032)$. The $100 \mathrm{hr}$ fuel in both fall 5 yr and fall $15 \mathrm{yr}$ treatments (Figure 1C) was less than the controls by $0.97 \mathrm{Mg} \mathrm{ha}^{-1}\left(t_{20.4}=\right.$ $2.71, P=0.013)$ and $0.90 \mathrm{Mg} \mathrm{ha}^{-1}\left(t_{20.4}=2.51\right.$, $P=0.021$ ), respectively. Similarly, the $100 \mathrm{hr}$ fuel in spring $5 \mathrm{yr}$ treatments was $1.21 \mathrm{Mg} \mathrm{ha}^{-1}$ less than the controls $\left(t_{20.4}=3.36, P=0.003\right)$ and $0.87 \mathrm{Mg} \mathrm{ha}^{-1}$ less (marginally significant) than the spring $15 \mathrm{yr}$ treatments $\left(t_{16}=2.01, P=\right.$ 0.061). There were no treatment differences for the $1000 \mathrm{hr}$ fuel class (all $P \geq 0.106$; Figure 1D).

By 2014, all reburn treatments had a minimum of $2.49 \mathrm{~cm}$ lower forest floor depth than the controls (all $t_{19.3} \geq 8.84, P \leq 0.001$; Figure $2)$. There were no statistical differences for forest floor depth between the fall and spring treatments at either frequency (all $P \geq 0.134$ ).

Consumption did not differ for $1 \mathrm{hr}$ or 100 hr fuels (Figure 3A and 3C) by season, fre-

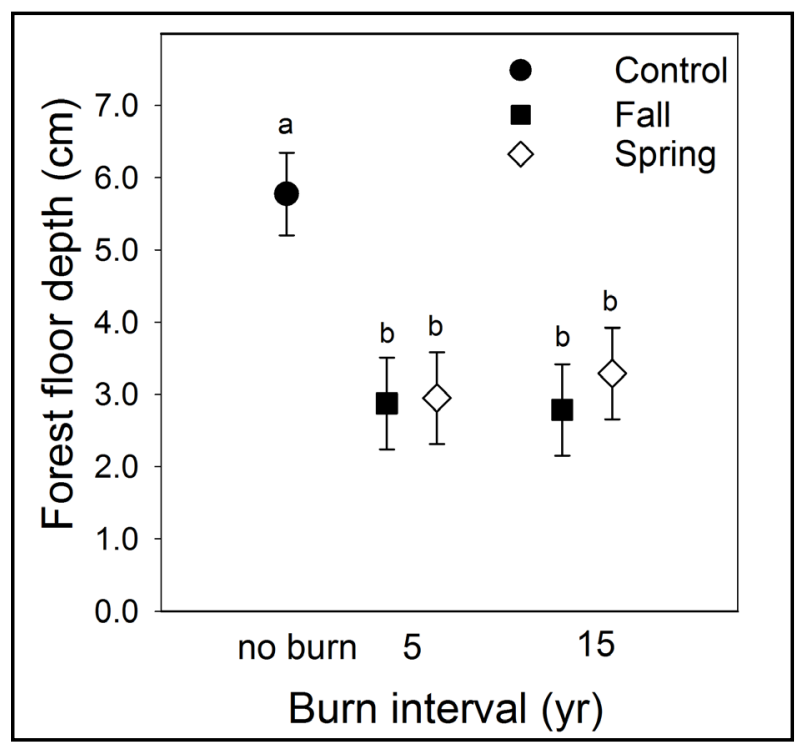

Figure 2. Forest floor fuel depth $(\mathrm{cm})$ in 2014 following spring and fall reburns at $5 \mathrm{yr}$ (three reburns) and $15 \mathrm{yr}$ (one reburn) frequencies in the Blue Mountain Ecoregion, Oregon, USA. Bars represent $95 \%$ confidence limits. Treatments not sharing the same letter are different at $\alpha=0.05$.

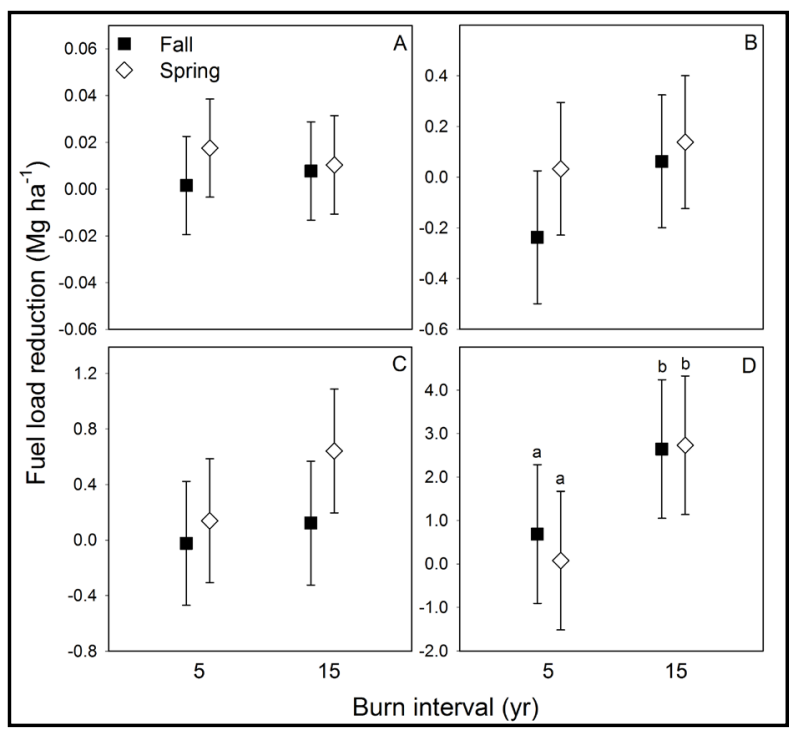

Figure 3. Woody surface fuel load reduction $(\mathrm{Mg}$ $\mathrm{ha}^{-1}$ ) of (A) $1 \mathrm{hr}$, (B) $10 \mathrm{hr}$, (C) $100 \mathrm{hr}$, and (D) $1000 \mathrm{hr}$ fuel size classes for the last spring and fall reburns at $5 \mathrm{yr}$ (reburn three) and $15 \mathrm{yr}$ (reburn one) frequencies in the Blue Mountain Ecoregion, Oregon, USA. Bars represent $95 \%$ confidence limits. Within fuel type, when differences exist, treatments not sharing the same letter are different at $\alpha=0.05$. 
quency, or their interaction in 2014 (all $P \geq$ 0.141 ). For $10 \mathrm{hr}$ fuels, there was a marginally significant seasonal effect overall $\left(F_{1,5}=4.60\right.$, $P=0.085$; Figure $3 \mathrm{~B}$ ), with spring reburns consuming $0.17 \mathrm{Mg} \mathrm{ha}^{-1}$ more $\left(t_{5}=2.15, P=0\right.$. 085) than the fall reburns, regardless of frequency $\left(F_{1,10}=0.55, P=0.474\right)$. Consumption of $1000 \mathrm{hr}$ fuel (Figure 3D) was significantly different for frequency overall $\left(F_{1,10}=14.72, P\right.$ $=0.003)$, with the $15 \mathrm{yr}$ treatments consuming $2.30 \mathrm{Mg} \mathrm{ha}^{-1}$ more $\left(t_{10}=3.84, P=0.003\right)$ than the $5 \mathrm{yr}$ frequency reburns. There was no season effect $\left(F_{1,5}=0.37, P=0.572\right)$, nor a season by frequency interaction $\left(F_{1,10}=0.34, P=\right.$ 0.574). Forest floor consumption differed by season overall $\left(F_{1,5}=21.23, P=0.006\right.$; Figure 4). The spring treatments consumed $0.19 \mathrm{~cm}$ more forest floor $\left(t_{5}=4.61, P=0.006\right)$ than the fall treatments. There was no frequency effect $\left(F_{1,10}=0.68, P=0.430\right)$, nor season by frequency interaction $\left(F_{1,10}=0.40, P=0.540\right)$.

Short seedlings $(\leq 0.4 \mathrm{~m})$ in the fall $5 \mathrm{yr}$ treatment were 6.1 times more abundant (Fig-

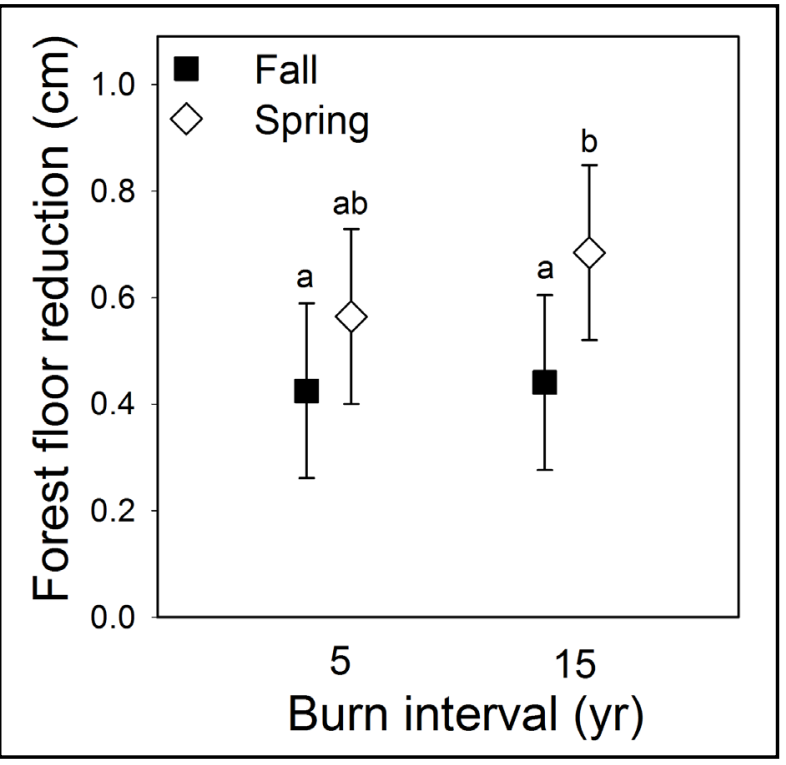

Figure 4. Forest floor fuel depth reduction $(\mathrm{cm})$ for the last spring and fall reburns at $5 \mathrm{yr}$ (third reburn) and 15 yr (first reburn) frequencies in the Blue Mountain Ecoregion, Oregon, USA. Bars represent $95 \%$ confidence limits. Treatments with the same letter are not different at $\alpha=0.05$. ure $5 \mathrm{~A})$ than the spring $15 \mathrm{yr}$ treatment $\left(t_{20.2}=\right.$ $3.67, P=0.002), 3.8$ times more than the control $\left(t_{16.2}=3.14, P=0.006\right), 3.6$ times more than the fall $15 \mathrm{yr}$ treatment $\left(t_{13}=2.53, P=\right.$ $0.025)$, and 2.8 times more than the spring $5 \mathrm{yr}$ treatment $\left(t_{20.2}=2.07, P=0.051\right.$; marginally different). There were no differences in short seedlings among any of the other treatments (all $P \geq 0.143)$. Tall seedlings $(>0.4 \mathrm{~m}$ to 1.37

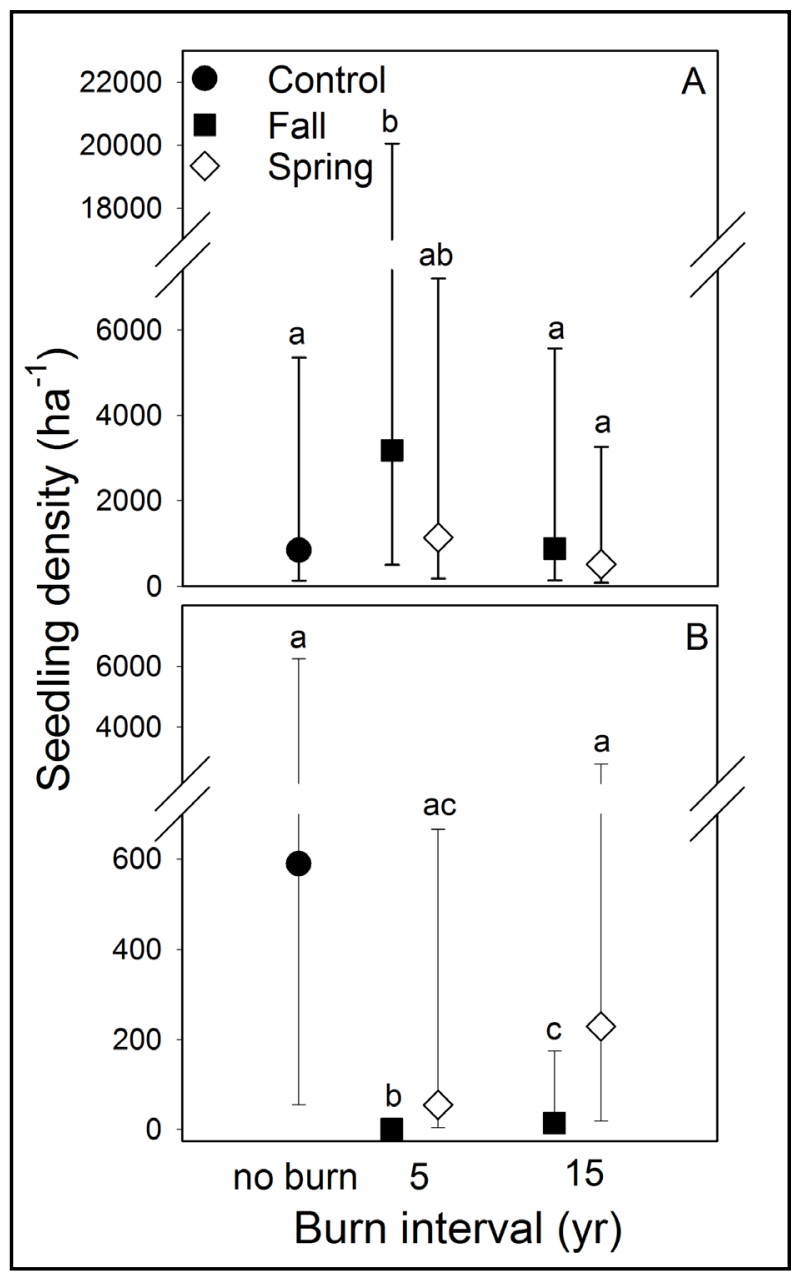

Figure 5. Total conifer seedling density (ha ${ }^{-1}$ ) for A) $\leq 0.4 \mathrm{~m}$ height, and B) $>0.4 \mathrm{~m}$ to $1.37 \mathrm{~m}$ height, in 2015, one year following spring and fall reburns at $5 \mathrm{yr}$ (three reburns) and $15 \mathrm{yr}$ (one reburn) frequencies in the Blue Mountain Ecoregion, Oregon, USA. Data were natural log transformed for analysis; back-transformed means and 95\% confidence limits are presented. Within height category, treatments with the same letter are not different at $\alpha=$ 0.05 . Note breaks in $y$-axes. 
$\mathrm{m})$ in the fall $5 \mathrm{yr}$ reburns were 0.002 times more abundant than the control $\left(t_{12.1}=5.52, P\right.$ $\leq 0.001), 0.005$ times more abundant than the spring $15 \mathrm{yr}$ treatment $\left(t_{15.8}=4.28, P \leq 0.001\right)$, 0.019 times more abundant than the spring 5 yr treatment $\left(t_{15.8}=3.14, P=0.006\right)$, and 0.074 times more abundant than the fall $15 \mathrm{yr}$ treatment $\left(t_{13.0}=2.52, P=0.025\right)$ (Figure 5B). Tall seedlings in fall $15 \mathrm{yr}$ reburns were 0.025 and 0.063 times more abundant than in the control $\left(t_{12.1}=3.24, P=0.007\right)$ and spring $15 \mathrm{yr}$ treatment $\left(t_{15.8}=2.20, P=0.043\right)$, respectively. The spring $5 \mathrm{yr}$ treatment resulted in 0.48 times as many tall seedlings than the control but the effect was only marginally significant $\left(t_{12.1}=2.07, P=0.060\right)$. There were no other treatment differences for tall seedlings (all $P \geq$ 0.190).

\section{Objective 2-Five Year Seasonal Reburn Dynamics}

Across the three $5 \mathrm{yr}$ frequency reburns (Figure 6), differences in surface fuel loads in all fuel classes were dependent on the year and treatment (Table 3), except for $1 \mathrm{hr}$ fuels. The largest changes were the spring treatment decline in $100 \mathrm{hr}$ fuels (Figure 6C), and the fall treatment increase in $1000 \mathrm{hr}$ fuels (Figure $6 \mathrm{D})$, both occurring between reburns one and two. Control treatments experienced large declines in $1 \mathrm{hr}, 10 \mathrm{hr}$, and $100 \mathrm{hr}$ fuels between 2003 and 2014, resulting in reduced differences from reburn treatments by 2014 . Forest floor depth also had a significant year by treatment interaction (Table 3), with the fall treatment gradually increasing in depth following each successive reburn, while the spring treatments decreased in depth through reburn two, then increased following reburn three (Figure 7).

Consumption of $1 \mathrm{hr}$ fuels did not change with 5 yr reburns (Table 4, Figure 8A), whereas $10 \mathrm{hr}$ fuel consumption was statistically different by both year and treatment (Table 4), with consumption decreasing for both fall and

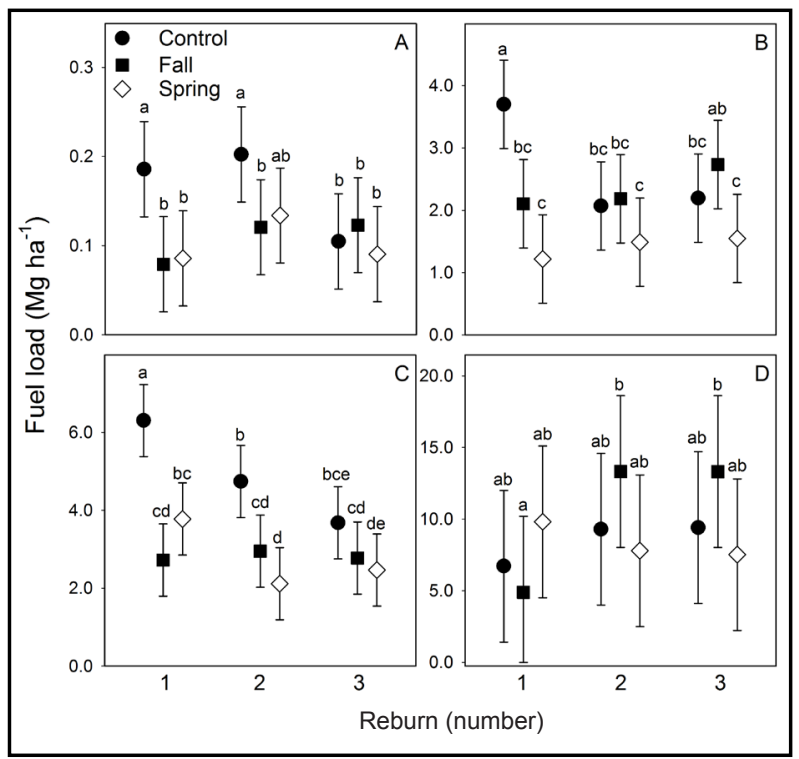

Figure 6. Woody surface fuel $\left(\mathrm{Mg} \mathrm{ha}^{-1}\right)$ of (A) 1 hr, (B) $10 \mathrm{hr}$, (C) $100 \mathrm{hr}$, and (D) $1000 \mathrm{hr}$ fuel size classes, following spring and fall reburns at $5 \mathrm{yr}$ frequencies in the Blue Mountain Ecoregion, Oregon, USA. Bars represent $95 \%$ confidence limits. Within fuel type, treatments with the same letter are not different at $\alpha=0.05$.

spring with each subsequent reburn (Figure 8B). For $100 \mathrm{hr}$ fuels, there was a significant year by treatment interaction (Table 4), with consumption decreasing for subsequent fall reburns; whereas for spring reburns, $100 \mathrm{hr}$ fuel consumption did not decrease until reburn three (Figure 8C). Consumption for $1000 \mathrm{hr}$ fuels was not statistically different by year, treatment, or their interaction (Table 4, Figure 8D). Forest floor consumption depended on year and treatment interaction (Table 4). There were no differences in forest floor consumption for spring reburns, but consumption increased for fall reburns (Figure 9).

Short seedling density also had a significant year by treatment interaction (Table 3), increasing incrementally with $5 \mathrm{yr}$ fall reburns, whereas the numbers stabilized with spring reburns (Figure 10A). In contrast, tall seedling density remained low in $5 \mathrm{yr}$ fall and spring reburns (Figure 10B). 
Table 3. Test statistics by surface fuel load $\left(\mathrm{Mg} \mathrm{ha}^{-1}\right)$, forest floor depth $(\mathrm{cm})$, and seedling density $\left(\mathrm{ha}^{-1}\right)$ for the 5-year frequency reburn randomized complete block repeated measures linear mixed model for the season and frequency of burn study in the Blue Mountain Ecoregion, Oregon, USA. Values for significant effects $\alpha=0.05$ are marked with an asterisk $(*)$. df is the degrees of freedom for which the first number is the numerator and the second number is the denominator to compute the $P$ value.

\begin{tabular}{|c|c|c|c|c|c|c|c|c|c|}
\hline \multirow[b]{2}{*}{ Response } & \multicolumn{3}{|c|}{ Year } & \multicolumn{3}{|c|}{ Treatment $^{\mathrm{a}}$} & \multicolumn{3}{|c|}{ Year $\times$ treatment } \\
\hline & $F$ & $P$ & df & $F$ & $P$ & df & $F$ & $P$ & df \\
\hline $1 \mathrm{~h}\left(\mathrm{Mg} \mathrm{ha}^{-1}\right)$ & 2.90 & 0.074 & $2,25.4$ & 5.77 & $0.007 *$ & $2,35.6$ & 1.90 & 0.141 & $4,25.4$ \\
\hline $10 \mathrm{~h}\left(\mathrm{Mg} \mathrm{ha}^{-1}\right)$ & 1.46 & 0.248 & 2,30 & 7.74 & $0.009 *$ & 2,10 & 4.44 & $0.006^{*}$ & 4,30 \\
\hline $100 \mathrm{~h}\left(\mathrm{Mg} \mathrm{ha}^{-1}\right)$ & 8.19 & $0.002 *$ & $2,27.3$ & 13.81 & $0.001 *$ & $2,11.4$ & 3.56 & $0.019 *$ & $4,27.3$ \\
\hline $1000 \mathrm{~h}\left(\mathrm{Mg} \mathrm{ha}^{-1}\right)$ & 2.65 & 0.087 & $2,30.7$ & 0.32 & 0.727 & $2,17.3$ & 2.75 & $0.046^{*}$ & $4,30.7$ \\
\hline Forest floor $(\mathrm{cm})^{\mathrm{b}}$ & 3.56 & $0.042 *$ & $2,28.6$ & 105.70 & $\leq 0.001 *$ & $2,10.7$ & 10.57 & $\leq 0.001$ & $4,28.6$ \\
\hline Short seedlings $\left(\mathrm{ha}^{-1}\right)^{\mathrm{c}}$ & 6.50 & $0.006^{*}$ & $2,23.2$ & 0.57 & 0.580 & $2,11.1$ & 23.20 & $0.007 *$ & $4,23.2$ \\
\hline Tall seedlings $\left(\mathrm{ha}^{-1}\right)^{\mathrm{d}}$ & 2.81 & 0.081 & $2,22.9$ & 13.55 & $0.002 *$ & $2,8.8$ & 1.65 & 0.196 & $2,22.9$ \\
\hline
\end{tabular}

${ }^{\mathrm{a}}$ Control (unburned), fall reburn, and spring reburn

${ }^{\mathrm{b}}$ Forest floor depth $(\mathrm{cm})$

c Short seedlings defined as $<0.4 \mathrm{~m}$

d Tall seedlings defined as $>0.4 \mathrm{~m}$ and $<1.37 \mathrm{~m}$

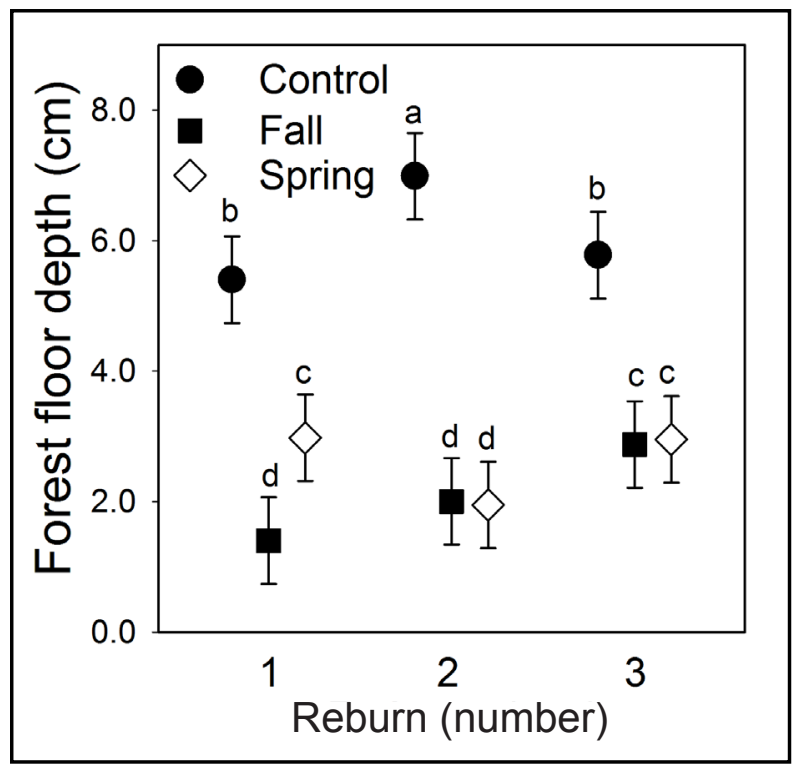

Figure 7. Forest floor fuel depth $(\mathrm{cm})$ following spring and fall reburns at $5 \mathrm{yr}$ frequencies in the Blue Mountain Ecoregion, Oregon, USA. Bars represent $95 \%$ confidence limits. Treatments with the same letter are not different at $\alpha=0.05$.

\section{DISCUSSION}

Fuel reduction is a key objective driving the use of thinning and prescribed fire in western US ponderosa pine forest restoration, yet there are few studies documenting post-treatment trends in forest floor and surface fuel loads (Keifer et al. 2006, Chiono et al. 2012, Vaillant et al. 2015), and even fewer examining effects after repeated burns (Webster and Halpern 2010, Higgins et al. 2015).

Similar to results from the southern Sierra Nevada Mountains of California (Webster and Halpern 2010), our reburns, regardless of season or frequency, were much less severe than the initial burns, causing very little crown scorch and no detectable increase in mortality over that of the unburned controls (D. Westlind, USDA Forest Service, Pacific Northwest Research Station, Forestry Sciences Laboratory, Corvallis, Oregon, USA, unpublished data). In our reburns, especially for the $5 \mathrm{yr}$ frequency, the fire crews often had difficulty getting the fires to spread, probably due to forest floor fuel load being lower than at the time of the initial burns. These subtle effects from 
Table 4. Test statistics, $P$ values, and degrees of freedom (df) for fuel consumption by fuel type from a randomized complete block repeated measures analysis for 5-year interval reburns for the season and frequency of burn study in the Blue Mountain Ecoregion, Oregon, USA. Values for significant effects $\alpha=$ 0.05 are marked with an asterisk $(*)$. df is the degrees of freedom for which the first number is the numerator and the second number is the denominator to compute the $P$ value.

\begin{tabular}{|c|c|c|c|c|c|c|c|c|c|}
\hline \multirow[b]{2}{*}{ Fuel type } & \multicolumn{3}{|c|}{ Year } & \multicolumn{3}{|c|}{ Treatment $^{\mathrm{a}}$} & \multicolumn{3}{|c|}{ Year $\times$ treatment } \\
\hline & $F$ & $\boldsymbol{P}$ & df & $F$ & $P$ & df & $F$ & $\boldsymbol{P}$ & df \\
\hline $1 \mathrm{hr}$ & 0.16 & 0.851 & $2,11.8$ & 0.03 & 0.876 & $1,4.3$ & 0.89 & 0.436 & $2,11.8$ \\
\hline $10 \mathrm{hr}$ & 9.32 & $0.003 *$ & $2,13.8$ & 21.85 & $0.008^{*}$ & $1,4.4$ & 0.11 & 0.898 & $2,13.8$ \\
\hline $100 \mathrm{hr}$ & 20.49 & $\leq 0.001 *$ & $2,6.8$ & 4.76 & 0.057 & $1,9.0$ & 10.08 & $0.009 *$ & $2,6.8$ \\
\hline $1000 \mathrm{hr}$ & 1.04 & 0.377 & $2,15.2$ & 0.65 & 0.439 & $1,10.5$ & 0.42 & 0.661 & $2,15.2$ \\
\hline Forest floor ${ }^{b}$ & 0.46 & 0.639 & $2,12.7$ & 16.61 & $0.010^{*}$ & $2,4.9$ & 4.45 & $0.034 *$ & $2,12.7$ \\
\hline
\end{tabular}

${ }^{\mathrm{a}}$ Fall or spring reburn

${ }^{\mathrm{b}}$ Litter and duff combined depth $(\mathrm{cm})$

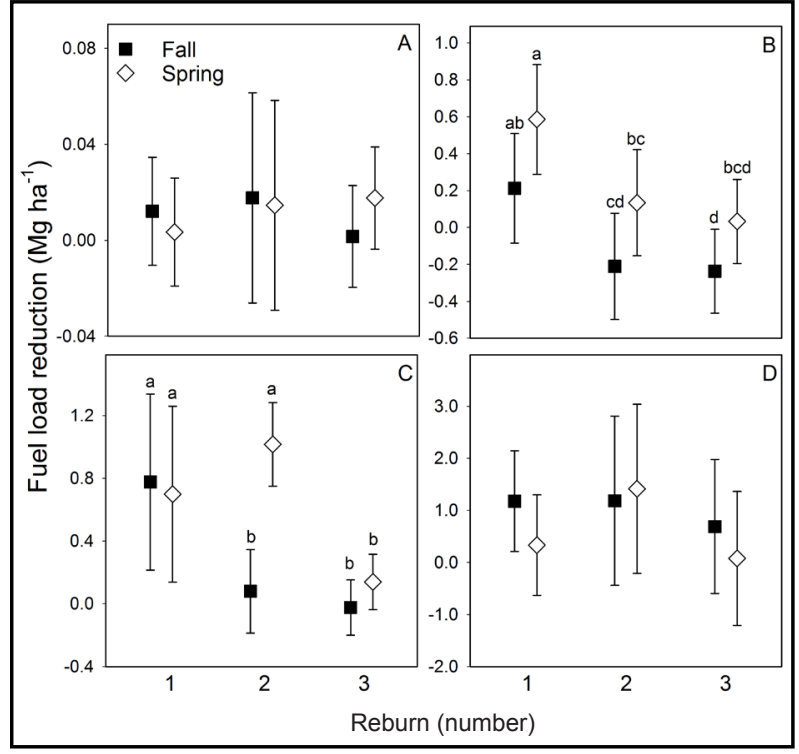

Figure 8. Woody surface fuel load reduction (Mg $\mathrm{ha}^{-1}$ ) of (A) $1 \mathrm{hr}$, (B) $10 \mathrm{hr}$, (C) $100 \mathrm{hr}$, and (D) $1000 \mathrm{hr}$ size classes, for spring and fall reburns at 5 yr frequencies, in the Blue Mountain Ecoregion, Oregon, USA. Bars represent $95 \%$ confidence limits. Within fuel type, when differences exist, treatments with the same letter are not different at $\alpha=0.05$.

reburning are consistent with those expected from very frequent but low-severity burns in low-elevation, dry pine sites in the western US (Agee 1996b, Hessburg et al. 2005), but also

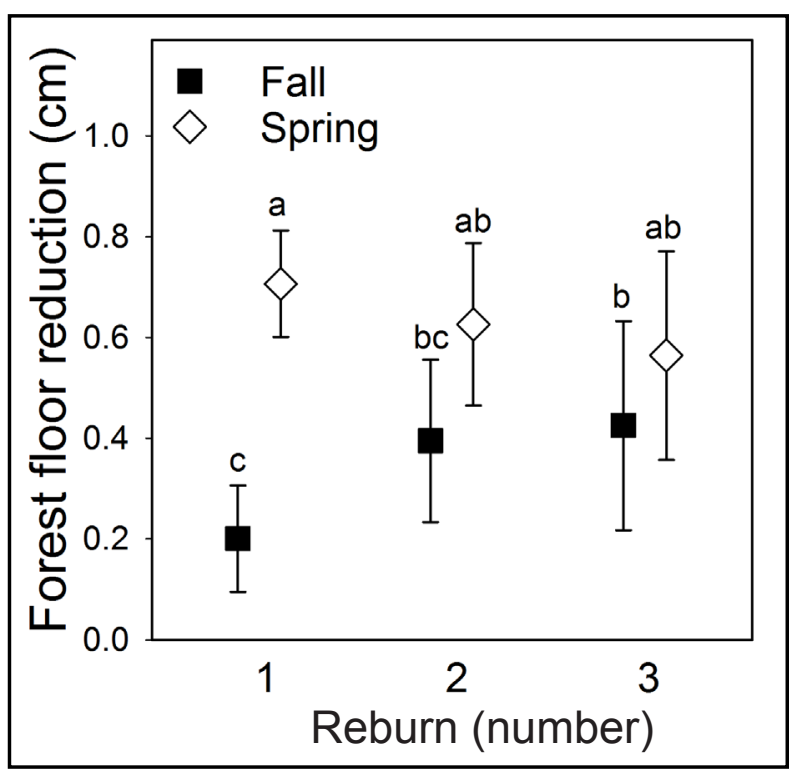

Figure 9. Forest floor fuel depth reduction (cm) for spring and fall reburns at $5 \mathrm{yr}$ frequencies, in the Blue Mountain Ecoregion, Oregon, USA. Bars represent $95 \%$ confidence limits. Treatments with the same letter are not different at $\alpha=0.05$.

are a consequence of the early and late seasonal timing of our reburns when fuel moisture is higher and air temperatures are lower than during in-season burns. These subtle reburn effects are also likely due to the relatively low productivity of our study sites (Kerns et al. 2011), limiting shrub, grass, and other fine fuel 


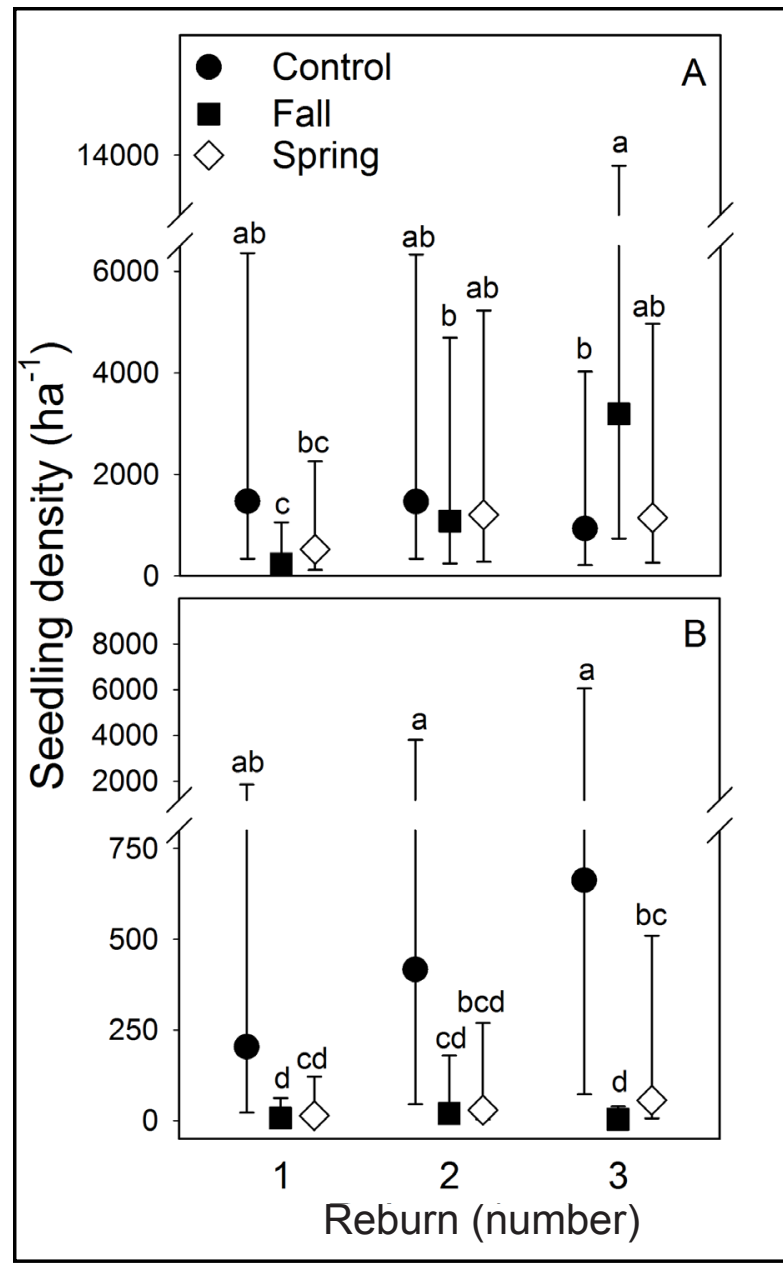

Figure 10. Total conifer seedling density $\left(\mathrm{ha}^{-1}\right)$ for A) $\leq 0.4 \mathrm{~m}$ height, and B) $>0.4 \mathrm{~m}$ to $1.37 \mathrm{~m}$ height, one year following spring and fall reburns at $5 \mathrm{yr}$ frequencies, in the Blue Mountain Ecoregion, Oregon, USA. Data were natural $\log$ transformed for analysis; back-transformed means and $95 \%$ confidence limits are presented. Within the seedling size category, treatments with the same letter are not different at $\alpha=0.05$.

development, in comparison to other more productive areas such as the southeastern US (Reilly et al. 2016) and the upper Midwest (Peterson and Reich 2001).

Our hypothesis that $5 \mathrm{yr}$ fall reburning would limit conifer regeneration more than spring or $15 \mathrm{yr}$ reburning was correct, but it was not correct that it would also reduce forest floor depth, or woody fuels. Interestingly, our spring 5 yr treatment ended up with the lowest woody fuels load across all four fuel sizes, and the fall $5 \mathrm{yr}$ treatment tended to have higher fuel load (except for $100 \mathrm{hr}$ fuels), although these differences were not always significant. This result is somewhat surprising given that others report initial entry fall burns consuming more fuel than spring burns (Knapp et al. 2005, Fettig et al. 2010), and the general assumption that shorter between-fire intervals prevent fuel buildup (Vaillant et al. 2015). The few differences we document for woody fuels in 2014 may be partly due to the highly variable nature of woody fuels within the stands, plus the difficulty and expense in adequately replicating a long-term field study such as this. But the differences we did document for all but $1000 \mathrm{hr}$ fuels following reburn one had all disappeared following reburn three. It appears that, for the control treatments, fuel loads are being reduced through decay, which is similar to results from other studies with thinning-only treatments (Youngblood et al. 2008, Vaillant et al. 2015), while fuel loads are stable (recruitment is equal to consumption) in the burn treatments, which resulted in the lack of treatment differences by the end of the study period.

Differences in severity of the initial entry burns heavily impacted our overall results. Fuel data was not collected prior to or immediately after our initial entry burns, but the initial entry fall burns were more severe than the initial entry spring burns. The initial fall burns caused nearly three times more mortality to the pine overstory $(\mathrm{dbh} \geq 7.0 \mathrm{~cm})$ than the initial spring burns (29\% and $11 \%$, respectively) (Thies et al. 2005). While plot area burned was similar for both seasons, the initial fall burns consumed more of the litter and duff mounds at the base of trees, and caused higher bole and crown scorching (Thies et al. 2005). Additionally, the initial entry fall burns resulted in significant reductions in the forest floor depth measured four years post burn, while spring burns did not (Kerns et al. 2011), a find- 
ing similar to another study in the Blue Mountain Ecoregion approximately $30 \mathrm{~km}$ to the north (Progar et al. 2017). The nearly 150\% increase we documented for $1000 \mathrm{hr}$ fuels in the fall $5 \mathrm{yr}$ reburn treatment between reburns one and two is due to the higher mortality in the initial fall burns. Transect-based methods like we used here count downed dead woody debris, so the standing dead trees killed by the initial entry burns are rarely recorded as fuel until they fall. But, even in dry climates, firekilled ponderosa pine begin falling within a few years, contributing limbs and stems to surface fuel loads. In southwestern Colorado, fire-killed ponderosa pine snags began falling within one to two years, with smaller diameter and trees killed by spring burns falling first, but, after 10 years, $75 \%$ of all fire-killed trees had fallen (Harrington 1996). The increased $1000 \mathrm{hr}$ fuel level we documented between reburns one and two in the fall $5 \mathrm{yr}$ treatments is maintained throughout the remainder of the study period and, with the slow decomposition rates of dry interior forests, in combination with low consumption of $1000 \mathrm{hr}$ fuel during the reburns (e.g., reburns two barely consumed $1 \mathrm{Mg} \mathrm{ha} \mathrm{a}^{-1}$ ), is likely to persist for considerable time. Although it did not reach the level of statistical significance in the 2014 analysis, a similar dynamic of increasing $1000 \mathrm{hr}$ fuels resulting from initial burn mortality also occurred in the fall $15 \mathrm{yr}$ treatments (D. Westlind, personal observation). Mortality from initial fires and subsequent snag and limb fall resulting in similar fuel increases following burning has been observed by others (Agee and Skinner 2005, Reinhardt et al. 2008).

We expected fall 5 yr reburning to continue to consume more fuel than spring reburning as found by others in initial burns (Knapp et al. 2005, Fettig et al. 2010, Progar et al. 2017). However, consumption of woody and forest floor fuels with repeated 5 yr burning was consistently low, and there was a lack of persistent seasonal consumption differences. Interestingly, the one seasonal effect we did detect for
$100 \mathrm{hr}$ fuels for reburn two showed more consumption for spring reburning. This general lack of seasonal difference is most likely due to reduced forest floor fuel, a result from the initial fall burn, suppressing any consumption advantage of lower fall fuel moisture. Indeed, the spring reburn one had nearly four times more forest floor consumption compared to fall reburn one, but that consumption difference declined as the forest floor fuel in the spring treatments was reduced with each successive reburn. With reburning, forest floor fuel consumption appears to be more a function of how much forest floor fuel remains rather than burn season, although burn season was important for the initial burn results.

Overall consumption of woody fuel in the reburns was very low, the lone exception being the $1000 \mathrm{hr}$ fuels size in the $15 \mathrm{yr}$ frequency treatments for both seasons, but even then consumption was only about $17 \%$ of the pre-burn total. Consumption of $1000 \mathrm{hr}$ fuels for the 15 yr frequency treatment in the spring equal to that of the fall is somewhat surprising since fuel moisture is higher in spring than in fall, especially for $1000 \mathrm{hr}$ fuels, having only surface drying after the winter snows (Estes et al. 2012). The higher $1000 \mathrm{hr}$ fuels consumption we documented for $15 \mathrm{yr}$ reburning is likely a result of the longer frequency between burns, allowing more forest floor and fine woody fuels to accumulate, adding to reburn severity. Additionally, the spring $15 \mathrm{yr}$ treatment had more forest floor fuel remaining prior to reburning, due to the lower consumption of the initial spring burns.

Conifer regeneration was impacted by both burn season and frequency. Ponderosa pine seedling regeneration in many areas of the western US exceeds the amount needed to maintain forested stands (Sackett and Haase 1998, Battaglia et al. 2008, Higgins et al. 2015). Seedlings, often occurring in scattered dense clusters, quickly contribute to excessive stand density and create a multi-layered canopy of ladder fuel that can substantially raise 
crown-fire potential (Fulé et al. 2004, Agee and Skinner 2005, Battaglia et al. 2008, Higgins et al. 2015). If the management goal is to maintain low crown-fire hazard, these seedlings need to be eliminated before reaching a more fire-resistant stage, with crowns safely above the flame lengths typical of low-severity reburns. Both Battaglia et al. (2008), for the Black Hills, and Bailey and Covington (2002), for Arizona, suggest regeneration densities of no more than $500 \mathrm{ha}^{-1}$. While highly variable due to the clustered nature of seedling establishment, all of our treatments exceeded that density when both seedling sizes are combined. Battaglia et al. (2008) found a 10-year burn frequency to be optimal for controlling excessive conifer seedlings and recommended no more than 15 years in the Black Hills. Our results indicate that, for the Blue Mountain Ecoregion, 15 years may be too long between burns for controlling regeneration through burning alone, especially when reburning is executed during the spring.

The need for repeated burning as a tool for maintaining low fire severity potential in Western forests has been widely accepted (Agee and Skinner 2005, Reinhardt et al. 2008, Hessburg et al. 2016). Initial fall burns can reduce downed dead woody fuel but, as documented here, those reductions may be temporary if accompanied by significant overstory mortality.
Initial spring burning can minimize overstory mortality but may need to be repeated several times and at shorter intervals. Further reducing large woody fuels may be difficult to achieve in either spring or fall reburn situations due to insufficient forest floor fuel to aid fire spread and add the heat output necessary to ignite the larger fuel. However, if retaining large downed wood is a management goal for wildlife habitat, our results indicate the frequent reburning has little effect.

Rather than frequent reburning, which is difficult for local units to achieve and may increase opportunities for introduction and spread of exotic species, a gradual move to more historically accurate seasonal ranges for reburning may be more effective at sustaining low wildfire severity potential. Either early or late season prescribed burns may be used as initial treatment, for ease of control, to achieve some surface fuel and forest floor reductions, and limit mortality of larger fire resistant trees. But, similar to Battaglia et al. (2008), Ryan et al. (2013) and Higgins et al. (2015), our results suggest that achieving and maintaining low surface fuels, shallow forest floor fuels, and high ladder fuels may require increased reburn severity by burning in summer or earlier in fall when temperatures are higher and humidity is lower.

\section{ACKNOWLEDGEMENTS}

This study was funded by the Joint Fire Sciences Program, National Fire Plan, and Forest Health Protection (USDA Forest Service, Special Technology Development Program). We thank W. Thies for initiating this study; the Malheur National Forest and the Emigrant Creek Ranger District for supporting and providing crews to implement the prescribed fires, particularly K. Valentine, R. Crisafi, G. Mackey, K. Higle, and D. Hill; the field crews who collected fuels data; A. Muldoon for statistical help; M. Day, R. Kelsey, and N. Vaillant for helpful comments and reviews during manuscript development; and the anonymous reviewers for helpful comments.

\section{LITERATURE CITED}

Aastveit, A.H., T. Almøy, I. Mejza, and S. Mejza. 2009. Individual control treatment in split-plot experiments. Statistical Papers 50: 697-710. doi: 10.1007/s00362-009-0253-5 
Abatzoglou, J.T., and A.P. Williams. 2016. Impact of anthropogenic climate change on wildfire across western US forests. Proceedings of the National Academy of Sciences 113: 1177011775. doi: 10.1073/pnas.1607171113

Agee, J.K. 1996a. Fire ecology of Pacific Northwest forests. Island Press, Washington, D.C., USA.

Agee, J.K. 1996b. Fire in the Blue Mountains: a history, ecology, and research agenda. Pages 119-145 in: R.G Jaindl and T.M.; Quigley, editors. Search for a solution: sustaining the land, people, and economy of the Blue Mountains. American Forests, Washington, D.C., USA.

Agee, J.K., and M.R. Lolley. 2006. Thinning and prescribed fire effects on fuels and potential fire behavior in an eastern Cascades forest, Washington, USA. Fire Ecology 2: 142-158. doi: 10.4996/fireecology.0202003

Agee, J.K., and C.N. Skinner. 2005. Basic principles of forest fuel reduction treatments. Forest Ecology and Management 211: 83-96. doi: 10.1016/j.foreco.2005.01.034

Akaike, H. 1981. Likelihood of a model and information criteria. Journal of econometrics 16: 3-14. doi: 10.1016/0304-4076(81)90071-3

Bailey, J.D., and W.W. Covington. 2002. Evaluating ponderosa pine regeneration rates following ecological restoration treatments in northern Arizona, USA. Forest Ecology and Management 155: 271-278. doi: 10.1016/S0378-1127(01)00564-3

Battaglia, M.A., F.W. Smith, and W.D. Shepperd. 2008. Can prescribed fire be used to maintain fuel treatment effectiveness over time in Black Hills ponderosa pine forests? Forest Ecology and Management 256: 2029-2038. doi: 10.1016/j.foreco.2008.07.026

Belsky, A.J., and D.M. Blumenthal. 1997. Effects of livestock grazing on stand dynamics and soils in upland forests of the Interior West. Conservation Biology: 315-327. doi: 10.1046/j.1523-1739.1997.95405.x

Bonnet, V.H., A.W. Schoettle, and W.D. Shepperd. 2005. Postfire environmental conditions influence the spatial pattern of regeneration for Pinus ponderosa. Canadian Journal of Forest Research 35: 37-47. doi: 10.1139/x04-157

Bork, J.L. 1984. Fire history in three vegetation types on the eastern side of the Oregon Cascades. Thesis, Oregon State University, Corvallis, USA.

Brown, J.K. 1974. Handbook for inventorying downed woody material. USDA Forest Service General Technical Report INT-16, Intermountain Forest \& Range Experiment Station, Ogden, Utah, USA.

Castello, J.D., D.J. Leopold, and P.J. Smallidge. 1995. Pathogens, patterns, and processes in forest ecosystems. BioScience 45(1): 16-24. doi: 10.2307/1312531

Chiono, L.A., K.L. O’Hara, M.J. De Lasaux, G.A. Nader, and S.L. Stephens. 2012. Development of vegetation and surface fuels following fire hazard reduction treatment. Forests 3: 700-722. doi: 10.3390/f3030700

Chojnacky, D.C. 1984. Volume and biomass for curlleaf cercocarpus in Nevada. USDA Forest Service General Technical Report INT-332, Intermountain Forest \& Range Experiment Station, Ogden, Utah, USA.

Covington, W.W., P.Z. Fulé, M.M. Moore, S.C. Hart, T.E. Kolb, J.N. Mast, S.S. Sackett, and M.R. Wagner. 1997. Restoring ecosystem health in ponderosa pine forests of the Southwest. Journal of Forestry 95: 23-29.

Covington, W.W., and M.M. Moore. 1994. Postsettlement changes in natural fire regimes and forest structure: ecological restoration of old-growth ponderosa pine forests. Journal of Sustainable Forestry 2: 153-181. doi: 10.1300/J091v02n01_07 
Dennison, P.E., S.C. Brewer, J.D. Arnold, and M.A. Moritz. 2014. Large wildfire trends in the western United States, 1984-2011. Geophysical Research Letters 41: 2928-2933. doi: 10.1002/2014GL059576

Estes, B.L., E.E. Knapp, C.N. Skinner, and F.C. Uzoh. 2012. Seasonal variation in surface fuel moisture between unthinned and thinned mixed conifer forest, northern California, USA. International Journal of Wildland Fire 21: 428-435. doi: 10.1071/WF11056

Fettig, C.J., K.D. Klepzig, R.F. Billings, A.S. Munson, T.E. Nebeker, J.F. Negrón, and J.T. Nowak. 2007. The effectiveness of vegetation management practices for prevention and control of bark beetle infestations in coniferous forests of the western and southern United States. Forest Ecology and Management 238: 24-53. doi: 10.1016/j.foreco.2006.10.011

Fettig, C.J., S.R. McKelvey, D.R. Cluck, S.L. Smith, and W.J. Otrosina. 2010. Effects of prescribed fire and season of burn on direct and indirect levels of tree mortality in ponderosa and Jeffrey pine forests in California, USA. Forest Ecology and Management 260: 207-218. doi: 10.1016/j.foreco.2010.04.019

Fulé, P.Z., J.E. Crouse, A.E. Cocke, M.M. Moore, and W.W. Covington. 2004. Changes in canopy fuels and potential fire behavior 1880-2040: Grand Canyon, Arizona. Ecological Modelling 175: 231-248. doi: 10.1016/j.ecolmodel.2003.10.023

Harrington, M.G. 1996. Fall rates of prescribed fire-killed ponderosa pine. USDA Forest Service Research Paper INT-RP-489, Intermountain Forest \& Range Experiment Station, Ogden, Utah, USA.

Hatten, J.A., D. Zabowski, A. Ogden, and W. Thies. 2008. Soil organic matter in a ponderosa pine forest with varying seasons and intervals of prescribed burn. Forest Ecology and Management 255: 2555-2565. doi: 10.1016/j.foreco.2008.01.016

Hessburg, P., B. Smith, R. Salter, R. Ottmar, and E. Alvarado. 2000. Recent changes (1930s-1990s) in spatial patterns of Interior Northwest forests, USA. Forest Ecology and Management 136: 53-83. doi: 10.1016/S0378-1127(99)00263-7

Hessburg, P.F., and J.K. Agee. 2003. An environmental narrative of inland northwest United States forests, 1800-2000. Forest Ecology and Management 178: 23-59. doi: 10.1016/ S0378-1127(03)00052-5

Hessburg, P.F., J.K. Agee, and J.F. Franklin. 2005. Dry forests and wildland fires of the inland northwest USA: contrasting the landscape ecology of the pre-settlement and modern eras. Forest Ecology and Management 211: 117-139. doi: 10.1016/j.foreco.2005.02.016

Hessburg, P.F., B.G. Smith, and R.B. Salter. 1999. Detecting change in forest spatial patterns from reference conditions. Ecological Applications 9: 1232-1252. doi: 10.1890/1051-0761(1999)009[1232:DCIFSP]2.0.CO;2

Hessburg, P.F., T.A. Spies, D.A. Perry, C.N. Skinner, A.H. Taylor, P.M. Brown, S.L. Stephens, A.J. Larson, D.J. Churchill, and N.A. Povak. 2016. Tamm review: management of mixed-severity fire regime forests in Oregon, Washington, and northern California. Forest Ecology and Management 366: 221-250. doi: 10.1016/j.foreco.2016.01.034

Heyerdahl, E.K., L.B. Brubaker, and J.K. Agee. 2001. Spatial controls of historical fire regimes: a multiscale example from the Interior West, USA. Ecology 82: 660-678. doi: 10.1890/0012-9658(2001)082[0660:SCOHFR]2.0.CO;2

Heyerdahl, E.K., D. McKenzie, L.D. Daniels, A.E. Hessl, J.S. Littell, and N.J. Mantua. 2008. Climate drivers of regionally synchronous fires in the Inland Northwest (1651-1900). International Journal of Wildland Fire 17: 40-49. doi: 10.1071/WF07024 
Higgins, A.M., K.M. Waring, and A.E. Thode. 2015. The effects of burn entry and burn severity on ponderosa pine and mixed conifer forests in Grand Canyon National Park. International Journal of Wildland Fire 24: 495-506. doi: 10.1071/WF13111

Johnston, J.D. 2016. Forest successional and disturbance dynamics in the southern Blue Mountains of eastern Oregon. Dissertation, Oregon State University, Corvallis, USA.

Kauffman, J.B., and R. Martin. 1989. Fire behavior, fuel consumption, and forest-floor changes following prescribed understory fires in Sierra Nevada mixed conifer forests. Canadian Journal of Forest Research 19: 455-462. doi: 10.1139/x89-071

Keifer, M., J.W. van Wagtendonk, and M. Buhler. 2006. Long-term surface fuel accumulation in burned and unburned mixed-conifer forests of the central and southern Sierra Nevada, CA (USA). Fire Ecology 2: 53-72. doi: 10.4996/fireecology.0201053

Kerns, B.K., M. Buonopane, W.G. Thies, and C. Niwa. 2011. Reintroducing fire into a ponderosa pine forest with and without cattle grazing: understory vegetation response. Ecosphere 2(5): 1-23. doi: 10.1890/ES10-00183.1

Kerns, B.K., W.G. Thies, and C.G. Niwa. 2006. Season and severity of prescribed burn in ponderosa pine forests: implications for understory native and exotic plants. Ecoscience 13: 4455. doi: 10.2980/1195-6860(2006)13[44:SASOPB]2.0.CO;2

Knapp, E.E., J.E. Keeley, E.A. Ballenger, and T.J. Brennan. 2005. Fuel reduction and coarse woody debris dynamics with early season and late season prescribed fire in a Sierra Nevada mixed conifer forest. Forest Ecology and Management 208: 383-397. doi: 10.1016/j.foreco. 2005.01.016

Kolb, P.F., D.L. Adams, and G.I. McDonald. 1998. Impacts of fire exclusion on forest dynamics and processes in central Idaho. Proceedings of the Tall Timbers Fire Ecology Conference 20: 210-218.

Littell, R.C., G.A. Milliken, W.W. Stroup, R.D. Wolfinger, and O. Schobenberger. 2006. SAS for mixed models, second edition. SAS Institute Inc., Cary, North Carolina, USA.

Littell, J.S., D. McKenzie, D.L. Peterson, and A.L. Westerling. 2009. Climate and wildfire area burned in western US ecoprovinces, 1916-2003. Ecological Applications 19: 1003-1021. doi: 10.1890/07-1183.1

Marlon, J.R., P.J. Bartlein, D.G. Gavin, C.J. Long, R.S. Anderson, C.E. Briles, K.J. Brown, D. Colombaroli, D.J. Hallett, and M.J. Power. 2012. Long-term perspective on wildfires in the western USA. Proceedings of the National Academy of Sciences 109: E535-E543. doi: 10.1073/pnas.1112839109

McCandliss, D.S. 2002. Prescribed burning in the Kings River ecosystems project area: lessons learned. Pages 37-46 in: J. Verner, technical coordinator. Proceedings of a symposium on the Kings River Sustainable Forest Ecosystems Project: progress and current status. USDA Forest Service General Technical Report PSW-GTR-183, Pacific Southwest Research Station, Albany, California, USA.

Miles, P.D., and W.B. Smith. 2009. Specific gravity and other properties of wood and bark for 156 tree species found in North America. USDA Forest Service Research Note NRS-38, Northern Research Station, Newtown Square, Pennsylvania, USA.

Mirov, N.T. 1967. The genus Pinus. Ronald Press, New York, New York, USA.

Mutch, R.W., S.F. Arno, J.K. Brown, C.E. Carlson, R.D. Ottmar, and J.L. Peterson. 1993. Forest health in the Blue Mountains: a management strategy for fire-adapted ecosystems. USDA Forest Service General Technical Report PNW GTR-310, Pacific Northwest Research Station, Portland, Oregon USA. 
Perrakis, D.D.B., and J.K. Agee. 2006. Seasonal fire effects on mixed-conifer forest structure and ponderosa pine resin properties. Canadian Journal of Forest Research 36: 238-254. doi: $10.1139 / \mathrm{x} 05-212$

Peterson, D.L., and K.W. Marcinkowski. 2014. Recent changes in climate and forest ecosystems. Pages 3-11 in: D.L. Peterson, J.M. Vose, and T. Patel-Weynand, editors. Climate change and United States forests. Advances in global change research, volume 57. Springer, Dordrecht, The Netherlands. doi: 10.1007/978-94-007-7515-2_1

Peterson, D.W., and P.B. Reich. 2001. Prescribed fire in oak savanna: fire frequency effects on stand structure and dynamics. Ecological Applications 11: 914-927. doi: 10.1890/ 1051-0761(2001)011[0914:PFIOSF]2.0.CO;2

Progar, R., K. Hrinkevich, E. Clark, and M. Rinella. 2017. Prescribed burning in ponderosa pine: fuel reductions and redistributing fuels near boles to prevent injury. Fire Ecology 13: 149-161. doi: 10.4996/fireecology.1301149

Pyne, S.J. 1982. Fire in America. A cultural history of wildland and rural fire. Princeton University Press, Seattle, Washington, USA.

Reilly, M.J., K. Outcalt, J.J. O'Brien, and D. Wade. 2016. Effects of repeated growing season prescribed fire on the structure and composition of pine-hardwood forests in the southeastern Piedmont, USA. Forests 8: 8. doi: 10.3390/f8010008

Reinhardt, E.D., R.E. Keane, D.E. Calkin, and J.D. Cohen. 2008. Objectives and considerations for wildland fuel treatment in forested ecosystems of the interior western United States. Forest Ecology and Management 256: 1997-2006. doi: 10.1016/j.foreco.2008.09.016

Ryan, K.C., E.E. Knapp, and J.M. Varner. 2013. Prescribed fire in North American forests and woodlands: history, current practice, and challenges. Frontiers in Ecology and the Environment 11: e15-e24. doi: 10.1890/120329

Ryan, K.C., and E.D. Reinhardt. 1988. Predicting postfire mortality of seven Western conifers. Canadian Journal of Forest Research 18: 1291-1297. doi: 10.1139/x88-199

Sackett, S.S., and S.M. Haase. 1998. Two case histories for using prescribed fire to restore ponderosa pine ecosystems in northern Arizona. Proceedings of the Tall Timbers Fire Ecology Conference 20: 380-389.

SAS. 2014. Base SAS 9.4 procedures guide. SAS Institute, Cary, North Carolina, USA.

Schwilk, D.W., J.E. Keeley, E.E. Knapp, J. McIver, J.D. Bailey, C.J. Fettig, C.E. Fiedler, R.J. Harrod, J.J. Moghaddas, and K.W. Outcalt. 2009. The national Fire and Fire Surrogate study: effects of fuel reduction methods on forest vegetation structure and fuels. Ecological Applications 19: 285-304. doi: 10.1890/07-1747.1

Short, K.C. 2015. Spatial wildfire occurrence data for the United States, 1992-2013 [FPA FOD_20150323]. 3rd edition. USDA Forest Service, Rocky Mountain Research Station, Fort Collins, Colorado, USA. <http://dx.doi.org/10.2737/RDS-2013-0009.3>. Accessed 10 March 2016.

Soeriaatmadja, R. 1966. Fire history of the ponderosa pine forests of the Warm Springs Indian Reservation. Dissertation, Oregon State University, Corvallis, USA.

Stephens, S.L., J.D. McIver, R.E. Boerner, C.J. Fettig, J.B. Fontaine, B.R. Hartsough, P.L. Kennedy, and D.W. Schwilk. 2012. The effects of forest fuel-reduction treatments in the United States. BioScience 62: 549-560. doi: 10.1525/bio.2012.62.6.6

Stephens, S.L., and J.J. Moghaddas. 2005. Experimental fuel treatment impacts on forest structure, potential fire behavior, and predicted tree mortality in a California mixed conifer forest. Forest Ecology and Management 215: 21-36. doi: 10.1016/j.foreco.2005.03.070 
Stephens, S.L., J.J. Moghaddas, C. Edminster, C.E. Fiedler, S. Haase, M. Harrington, J.E. Keeley, E.E. Knapp, J.D. McIver, and K. Metlen. 2009. Fire treatment effects on vegetation structure, fuels, and potential fire severity in western US forests. Ecological Applications 19: 305320. doi: 10.1890/07-1755.1

Thies, W.G., D.J. Westlind, and M. Loewen. 2005. Season of prescribed burn in ponderosa pine forests in eastern Oregon: impact on pine mortality. International Journal of Wildland Fire 14: 223-231. doi: 10.1071/WF04051

USDA NRCS [US Department of Agriculture Natural Resources Conservation Service]. 2012. National Weather and Climate Center SNOTEL data: Oregon Rock Springs Site. <http:// www.wcc.nrcs.usda.gov/nwcc/site?sitenum=721>. Accessed 5 October 2015.

Vaillant, N.M., E.K. Noonan-Wright, A.L. Reiner, C.M. Ewell, B.M. Rau, J.A. Fites-Kaufman, and S.N. Dailey. 2015. Fuel accumulation and forest structure change following hazardous fuel reduction treatments throughout California. International Journal of Wildland Fire 24: 361-371. doi: 10.1071/WF14082

Webster, K.M., and C.B. Halpern. 2010. Long-term vegetation responses to reintroduction and repeated use of fire in mixed-conifer forests of the Sierra Nevada. Ecosphere 1: 1-27. doi: 10.1890/ES10-00018.1

Westerling, A.L., A. Gershunov, T.J. Brown, D.R. Cayan, and M.D. Dettinger. 2003. Climate and wildfire in the western United States. Bulletin of the American Meteorological Society 84: 595-604. doi: 10.1175/BAMS-84-5-595

Westerling, A.L., H.G. Hidalgo, D.R. Cayan, and T.W. Swetnam. 2006. Warming and earlier spring increase western US forest wildfire activity. Science 313: 940-943. doi: 10.1126/ science. 1128834

Youngblood, A., C.S. Wright, R.D. Ottmar, and J.D. McIver. 2008. Changes in fuelbed characteristics and resulting fire potentials after fuel reduction treatments in dry forests of the Blue Mountains, northeastern Oregon. Forest Ecology and Management 255: 3151-3169. doi: 10.1016/j.foreco.2007.09.032

Zald, H.S., A.N. Gray, M. North, and R.A. Kern. 2008. Initial tree regeneration responses to fire and thinning treatments in a Sierra Nevada mixed-conifer forest, USA. Forest Ecology and Management 256: 168-179. doi: 10.1016/j.foreco.2008.04.022 